\title{
Radiographic and Scintigraphic Correlation in a Patient with Pulmonary Alveolar Microlithiasis
}

\author{
Pulmoner Alveoler Mikrolitiyazisli bir Hastada Radyografik ve Sintigrafik \\ Korelasyon
}

Arzu Cengiz', Emel Ceylan², Can Zafer Karaman ${ }^{3}$

\begin{abstract}
Pulmonary alveolar microlithiasis (PAM) is a rare, idiopathic lung disease that leads to alveolar deposition of calcium phosphate microliths. Most patients are asymptomatic, but radiological features are quite marked and are nearly pathognomonic. Bone scintigraphy can be useful in the detection of early pulmonary calcifications. The imaging findings of a 65 year-old male patient who was diagnosed with PAM are described in this report. He presented with nonspecific chest pain, shortness of breath, wheezing, and a cough ongoing for 4 years. There was fine reticular and nodular infiltration seen on a chest $X$-ray. Chest computed tomography images revealed bilateral, diffuse, fine, calcified interstitial nodules and nodular septal thickening in the middle and lower lung zones. A whole body bone scintigraphy with technetium-99m methylene diphosphonate (Tc-99m MDP) revealed bilateral, diffuse uptake in the pulmonary parenchyma.
\end{abstract}

Key words: Pulmonary alveolar microlithiasis, X-Ray computed tomography, bone scintigraphy.

\section{Özet}

Pulmoner alveolar mikrolitiyazis (PAM), alveoler kalsiyum fosfat mikrolitlerinin birikimine yol açan, nedeni bilinmeyen nadir bir hastalıktır. Hastaların çoğu asemptomatiktir, fakat radyolojik özellikleri oldukça gürültülü ve neredeyse patognomoniktir. Kemik sintigrafisi erken pulmoner kalsifikasyonların saptanmasında kullanılabilir. Bu yazıda, PAM tanısı alan 65 yaşında bir erkek hastanın görüntüleme bulguları sunulmuştur. Hasta, dört yıldır devam eden nonspesifik göğüs ağrısı, nefes darlığı, hırılłı ve öksürük şikayetleriyle başvurdu. Akciğer grafisinde ince retiküler ve nodüler infiltrasyon vardı. Toraks bilgisayarlı tomografisi, bilateral orta ve alt zonlarda ince kalsifiye intersitisyel nodüller ve septal kalınlaşma gösterdi. Teknesyum 99m metilen difosfonat (Tc-99m MDP) ile yapılan tüm vücut kemik sintigrafisinde pulmoner parankimde bilateral diffüz tutulum izlendi.

Anahtar Sözcükler: Pulmoner alveoler mikrolitiyazis, XRay bilgisayarlı tomografi, kemik sintigrafisi.
Pulmonary alveolar microlithiasis (PAM) is a rare, diffuse lung disease characterized by the extensive intra-alveolar accumulation of calcispherites, which are salts of calcium and phosphate, in the absence of any known disorder of calcium meta- bolism. The etiology of PAM remains unclear; however, $50 \%$ of cases are familial (1). It has been described in all age groups and the mean age at diagnosis is 35 years. A gender predominance has not been observed $(2,3)$. Although the symptoms

\footnotetext{
'Department of Nuclear Medicine, Adnan Menderes University Faculty of Medicine, Aydın, Turkey

'Adnan Menderes Üniversitesi Tıp Fakültesi, Nükleer Tıp Anabilim Dalı, Aydın

2Department of Chest Disease, Adnan Menderes University, Facul- $\quad$ 2Adnan Menderes Üniversitesi Tıp Fakültesi, Göğüs Hastalıkty of Medicine, Aydın, Turkey

${ }^{3}$ Department of Radiology, Adnan Menderes University, Faculty of ları Anabilim Dalı, Aydın

${ }^{3}$ Adnan Menderes Üniversitesi Tıp Fakültesi, Radyoloji AnabiMedicine, Aydın, Turkey lim Dalı, Aydın
}

Submitted (Başvuru tarihi): 17.12.2017 Accepted (Kabul tarihi): 18.01.2018

Correspondence (iletişim): Arzu Cengiz, Department of Nuclear Medicine, Adnan Menderes University Faculty of Medicine, Aydın, Turkey e-mail: arzukincengiz@gmail.com 
may be unremarkable, radiological features are quite vivid and are nearly pathognomonic. Chest radiographs usually reveal diffuse, bilateral areas of micronodular calcifications that predominate in the middle and lower lung areas. CT scans show numerous, sand-like calcifications throughout the lungs with subpleural and peribronchial distribution. Bone scanning with $99 \mathrm{mTc}$ diphosphonate usually reveals diffuse, intense uptake throughout both lungs (4-6).

In this case report, the imaging methods used in the PAM diagnosis of a patient are described.

\section{CASE}

A 65-year-old man presented with a history of nonspecific chest pain, shortness of breath, wheezing, and a cough ongoing for 4 years. He had substernal burning in the chest that increased with breathing and he reported persistent chest pain on the right chest wall and that his cough increased in the presence of dust. He also complained of fatigue and headache. He had a 25-pack-year smoking history, but he had quit 35 years earlier. He had been suffering from gastric symptoms compatible with gastroesophageal reflux for 25 years, and hypertension for 10 years. As a result of changes on his chest $X$-ray and thorax computed tomography (CT) images, a lung biopsy had been recommended 10 years ago, but he had declined because of a lack of symptoms at the time. There was no known family history of respiratory diseases. A physical examination revealed normal vital signs with a pulse rate of $76 /$ minute, blood pressure of 135/78 $\mathrm{mmHg}$, and saturation of $96 \%$. There was no sign of dyspnea, cyanosis, edema, or clubbing. A physical examination of the chest was normal, with the exception of minimal crackles in both basal lungs and a wheeze on forced expiration. Blood test findings, including serum calcium concentration, were normal.

Pulmonary function tests demonstrated normal findings with forced expiratory volume in the first second (FEV1) was $2.36(81.2 \%)$ liters, the forced vital capacity (FVC) was 3.09 (82.7\%), and the ratio of FEV1/FVC was $76.4 \%$. A reversibility test was negative.

There was fine reticular and nodular infiltration observed on a chest $X$-ray, with numerous fine calcifications dispersed to the middle and lower lung zones (Figure 1). The findings were more pronounced in the central areas obscuring the mediastinal borders, but the diaphragmatic outlines were protected.

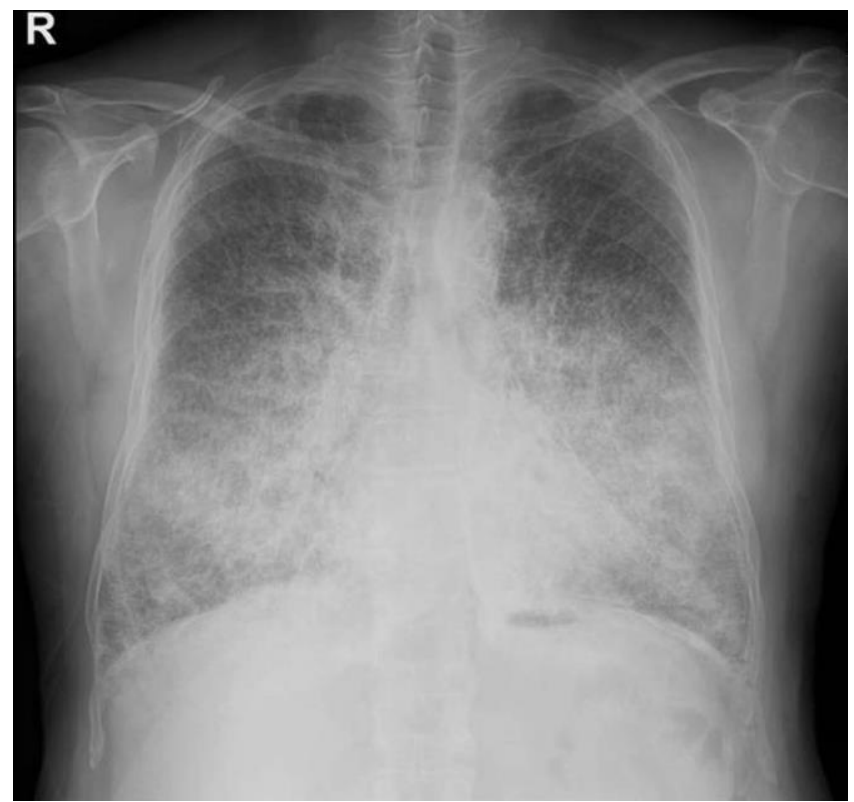

Figure 1: Plain chest radiography showing fine reticular and nodular infiltration with numerous fine calcifications dispersed to the middle and lower lung zones

A chest CT and high resolution computed tomography (HRCT) revealed bilateral, diffuse, randomly distributed, fine, calcified, interstitial nodules and nodular septal thickening in the middle and lower lung zones (Figure 2). Together with the diffuse but centrally located groundglass attenuations, the typical crazy paving pattern was apparent in the mid to lower lung zones. The nodules became more intense in the subpleural areas, close to the diffusely calcified pleural surfaces.

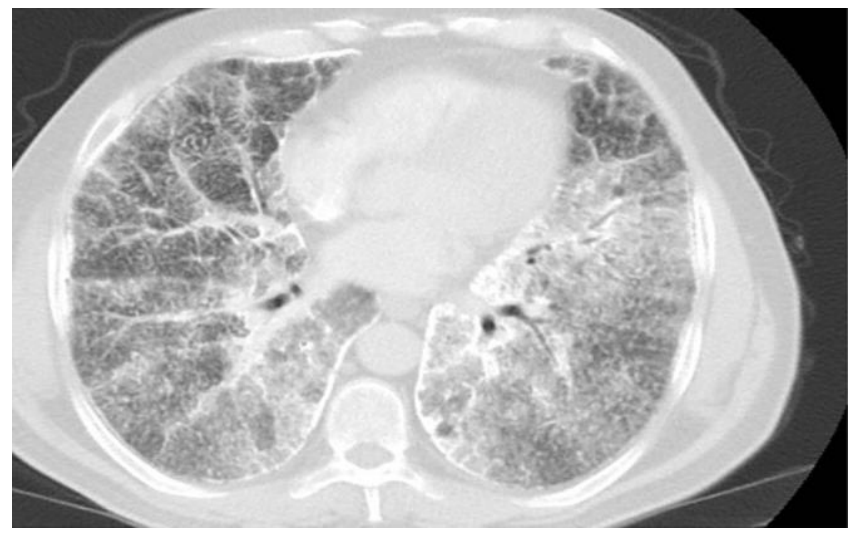

Figure 2: Chest computed tomography image revealing bilateral, diffuse, randomly distributed fine, calcified interstitial nodules and nodular septal thickening in the middle and lower lung zones

Whole body bone scintigraphy was performed after intravenous administration of $20 \mathrm{mCi}(740 \mathrm{MBq})$ technetium99m methylene diphosphonate (Tc-99m MDP). The bone scan revealed diffusely increased Tc-99m MDP uptake in both lungs. In accordance with radiological imaging 
methods, radiotracer uptake was concentrated at the base of the lungs on bone scintigraphy (Figure 3).

The patient was diagnosed with pulmonary alveolar microlithiasis (PAM) according to radiological and radionuclide imaging. Because the patient did not agree to an invasive procedure, bronchoscopic examination for histopathological evaluation could not be performed.

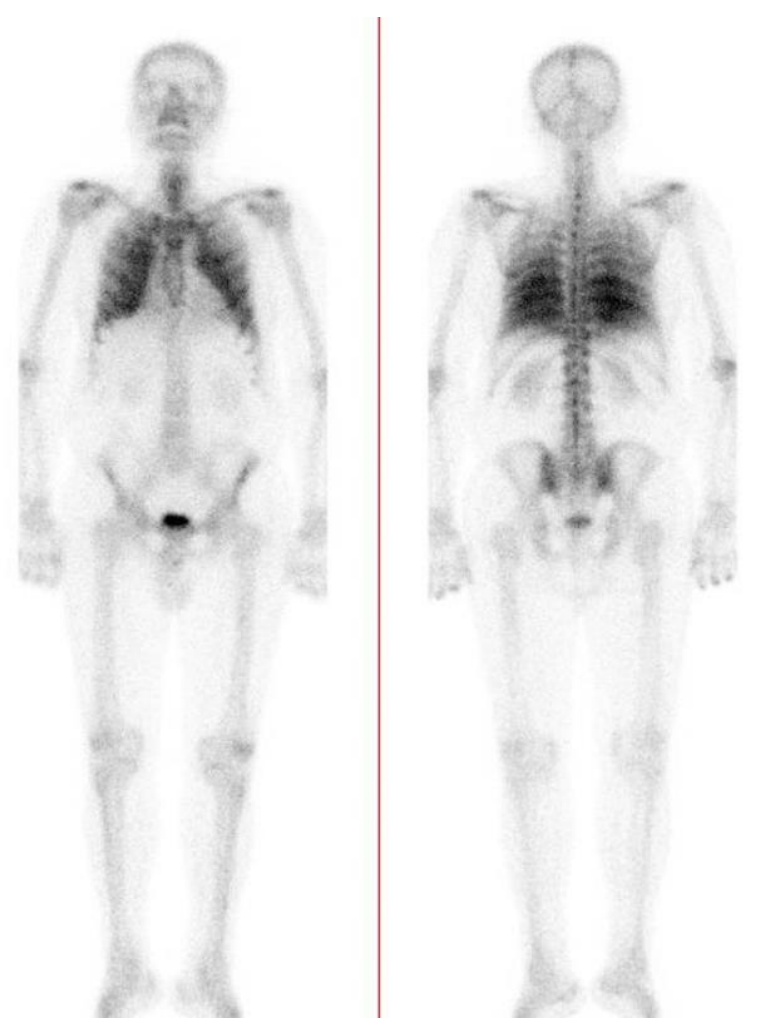

Figure 3: Bone scintigraphy showing intense bilateral uptake of technetium-99m methylene diphosphonate in the lungs. Increased uptake was predominantly located in the lower lung regions

\section{DISCUSSION}

PAM is a rare disease characterized by intra-alveolar calcium deposits. Most patients are asymptomatic and diagnosed incidentally. Calcification in extrapulmonary sites has also been reported, including the pericardium, prostate, and seminal vesicles $(7,8)$.

Because PAM appears to be familial in about half of the cases, family members of the patient should be screened using chest radiography after any person in the family has been diagnosed with PAM. Family members of our patient were scanned and none were diagnosed with PAM.

While in some cases, the illness has demonstrated slow progression, in other cases, it has worsened over time and lead to pulmonary fibrosis, respiratory failure, and cor-pulmonale. The most common symptoms are dyspnea, cough, chest pain, sporadic hemoptysis, and asthenia (9). In our patient, the major symptoms were a cough and nonspecific chest pain. There was no increase in his complaints during follow-up.

Imaging findings are highly diagnostic in patients with PAM. Chest radiography usually reveals scattered bilateral micronodular calcifications that have a "sandstorm" appearance. In these patients, small thin-walled subpleural cysts are responsible for the "black pleura" sign seen in the chest radiography. It can be detected more clearly with CT imaging. Tomographic changes are predominant in the inferior and posterior portions of the lungs $(4,9,10)$. On HRCT imaging, the crazy-paving pattern is considered to be very specific and pathognomonic of PAM. This pattern is defined as areas of ground-glass opacity with a thickening of the interposed interlobular septa, which occurs due to the accumulation of calculi in the peripheries of secondary pulmonary lobules (11). Due to the good correlation between the chest $\mathrm{CT}$ findings and pathological findings, the diagnosis of PAM can be made on the basis of the typical radiological pattern (9).

Bone scintigraphy is an imaging method that may be used to diagnose PAM. A bone scan usually reveals diffuse, intense uptake throughout both lungs, as seen in our patient. Although several mechanisms have been described for this finding, chemical absorption of hydroxyapatite crystals is largely accepted (12). Bone scintigraphy may be useful in the detection of early, small pulmonary calcified nodules that cannot be detected with conventional radiography (6). In conclusion, PAM is a rare disease that has very typical and pathognomonic imaging findings. Bone scintigraphy may be useful, especially in the early phases of the disease when the classic radiographical findings are not yet visible.

\section{CONFLICTS OF INTEREST}

None declared.

\section{AUTHOR CONTRIBUTIONS}

Concept - A.C., E.C., C.Z.K.; Planning and Design - A.C., E.C., C.Z.K.; Supervision - A.C., E.C., C.Z.K.; Funding A.C., E.C., C.Z.K.; Materials - E.C.; Data Collection and/or Processing - A.C.; Analysis and/or Interpretation A.C., E.C., C.Z.K.; Literature Review - A.C., E.C., C.Z.K.; Writing - A.C., E.C., C.Z.K.; Critical Review - A.C., E.C., C.Z.K.

\section{YAZAR KATKILARI}

Fikir - A.C., E.C., C.Z.K.; Tasarım ve Dizayn - A.C., E.C., C.Z.K.; Denetleme - A.C., E.C., C.Z.K.; Kaynaklar - A.C., E.C., C.Z.K.; Malzemeler - E.C.; Veri Toplama ve/veya 
İşleme - A.C.; Analiz ve/veya Yorum - A.C., E.C., C.Z.K.; Literatür Taraması - A.C., E.C., C.Z.K.; Yazıyı Yazan A.C., E.C., C.Z.K.; Eleştirel İnceleme - A.C., E.C., C.Z.K.

\section{REFERENCES}

1. Sosman MC, Dodd GD, Jones WD, Pillmore GU. The familial occurrence of pulmonary alveolar microlithiasis. Am J Roentgenol Radium Ther Nucl Med 1957; 77: 947-1012.

2. Castellana G, Lamorgese V. Pulmonary alveolar microlithiasis. World cases and review of the literature. Respiration 2003; 70:549-55. [CrossRef]

3. Mariotta S, Ricci A, Papale M, De Clementi F, Sposato B, Guidi $L$, et al. Pulmonary alveolar microlithiasis: report on 576 cases published in the literature. Sarcoidosis Vasc Diffuse Lung Dis 2004; 21:173-81.

4. Marchiori E, Gonçalves CM, Escuissato DL, Teixeira KI, Rodrigues R, Barreto MM, et al. Pulmonary alveolar microlithiasis: high-resolution computed tomography findings in 10 patients. J Bras Pneumol 2007; 33: 552-7. [CrossRef]

5. Khaladkar SM, Kondapavuluri SK, Kamal A, Kalra R, Kuber R. Pulmonary alveolar microlithiasis - clinicoradiological dissociation - a case report with radiological review. J Radiol Case Rep 2016; 31:14-21. [CrossRef]
6. Shah M, Joshi JM. Bone scintigraphy in pulmonary alveolar microlithiasis. Indian J Chest Dis Allied Sci 2011; 53:221-3.

7. Arslan A, Yalin T, Akan H, Belet U. Pulmonary alveolar microlithiasis associated with calcifications in the seminal vesicles. J Belge Radiol 1996; 79:1 18-9.

8. Kashyap S, Mohapatra PR. Pulmonary alveolar microlithiasis. Lung India 2013; 30:143-7. [CrossRef]

9. Ferreira Francisco FA, Pereira e Silva JL, Hochhegger B, Zanetti G, Marchiori E. Pulmonary alveolar microlithiasis. State-of-the-art review. Respir Med 2013; 107:1-9. [CrossRef]

10. Cluzel P, Grenier P, Bernadac P, Laurent F, Picard JD. Pulmonary alveolar microlithiasis: CT findings. J Comput Assist Tomogr 1991; 15:938-42. [CrossRef]

11. Gasparetto EL, Tazoniero P, Escuissato DL, Marchiori E, Frare E Silva RL, Sakamoto D. Pulmonary alveolar microlithiasis presenting with crazy-paving pattern on high resolution CT. Br J Radiol 2004; 77:974-6. [CrossRef]

12. Fallahi B, Ghafary BM, Fard-Esfahani A, Eftekhari M. Diffuse pulmonary uptake of bone-seeking radiotracer in bone scintigraphy of a rare case of pulmonary alveolar microlithiasis. Indian J Nucl Med 2015; 30:277-9. [CrossRef] 